\title{
Status and Issues of Digital Literacy of Secondary School Teachers
}

\author{
Abhaya Parida* and Swatirasmi Rout \\ Research Scholar, Regional Institute of Education, Bhubaneswar, Odisha, India \\ *Corresponding author: abhayparida666@gmail.com
}

Received: $20-04-2021$

Revised: 24-07-2021

Accepted: 03-08-2021

\begin{abstract}
Digital devices and applications are widely using by the schools . Various committees and commissions have also emphasized to use digital technologies in educational field. Nep 2020, NCTE regulation 2014 has also emphasized on digital literacy and applications of ICT in the teaching learning process. Government of India has launched the various programmes like digital India campaign, e-pathshala, NROER, Swayam, Swayamprava, NDL India etc. For facilitating he use of ICT in education sector. The present study is intended to find out the status and issues of digital literacy of secondary school teachers in Odisha. For conducting the study descriptive survey method was used over 40 secondary school teachers in Odisha whose were selected through purposive sampling technique. Data was collected through a self developed questionnaire and collected by the help of google form and telephonic interview. The collected data were analyzed by using frequency and percentage and accordingly conclusions were drawn. The study found that majority of teachers can change screen brightness and contrast, minimize, maximize and move window screen, use search command to locate a file and download and install applications in their devices. Most of them are aware about computer hardware devices and able to operate those. They are using digital technologies for searching, sharing and collecting data for educational practices. Google meet is popularly used as online teaching application. They suggested to improve the situation by providing in-service training programs, appointing sufficient computer teachers and providing sufficient infrastructure for digital learning.
\end{abstract}

Keywords: Digital Literacy (DL), Secondary School Teacher, ICT

"If a student is not fluent in multiple forms of media, I would venture to say that they won't necessarily be considered literate"

In the era of $21^{\text {st }}$ century man has moved to the mars due to advancement of science and technology. No aspects of human life has remain untouched with ICT. Each and every sector has been digitalized. The meaning of literate is not merely mean the ability to read and write rather it includes the ability to use ICT tools, applications, use of modern technologies, solving mathematical problems by using smart applications etc. According to Gilster (1997) digital literacy refers to the ability to understand and use information in multiple formats from a wide range of sources when it is presented via computers.
- Nichole Pinkard, Founder, Digital Youth Network

In this context, digital literacy has become more than the ability to use computers, smart phones and doing numerical calculation by the help of calculators. It consists of creation, consumption, location and communication of digital contents through the help of social networks and various professional skills and wide range services.

How to cite this article: Parida, A. and Rout, S. (2021). Status and Issues of Digital Literacy of Secondary School Teachers. Educational Quest: An Int. J. Edu. Appl. Soc. Sci., 12(2): 77-84.

Source of Support: None; Conflict of Interest: None (क) क 


\section{Digital Literacy: The Concept}

Digital literacy is a compound word consisting of two words i.e. digital and literacy. Digital refers to the electronic technologies, devices, modern applications, ICT tools which operates, stores, analyzed and process data for specific purposes. Literacy means the ability of reading and writing. According to UNESCO (2004, p.13), literacy is the ability to identify, understand, interpret, create, communicate and compute by using printed and written materials associated with varying contexts. Literacy involves a continuum of learning which enables the individuals to achieve their goals, to develop their knowledge and potential, and to participate fully in community and wider society. Fryer (2003) argue that literacy is a wide term reflecting a society's need for information and also suggests that the definition of a literate individual changes as information use within society increases. Jones and Flannigan (2006) state that due to rapid development in technological sector, society have changed and given new definitions to the term literacy. They also claim that the new generation needs to grow up with digital abilities to be able to manage productively in such a rapidly changing and multi-dimensional digital world. So in $21^{\text {st }}$ century it is not confined into reading and writing rather it is the ability to use ICT infrastructures, applications to do the everyday works.

Digital literacy consists of collecting information by using digital technologies, organizing information, analyzing, interpreting, evaluating, transferring and also reading and writing digital texts through the information production process (Akkoyunlu \& Soylu, 2010). Eshet (2002) states that digital literacy is individuals' ability, having complex, cognitive, psycho-motor, and affective skills in order to work efficiently in digital areas, rather than as using a software or a digital device. Blackall (2005) states that now a days literacy skills consists of the ability to understand the power of visuals and sounds, ability to use and define the power, ability to carry visuals and sounds into the digital contexts, ability to convert visuals and sounds into new formats and also the ability to publish visuals and sounds. For instance, abilities to share photos, write something and read on social network sites can be given as examples of digital literacy. The digital literacy high-level expert group (2008) defines the concept of digital literacy, which is the skill acquisition process, as: "digital literacy is essential for achieving digital competence, using ICT critically and confidentially for working, leisure, learning and communication."

Digital literacy is an innovative practice that emerged in the 1990s during the era of the internet revolution. Before that "computer literacy" was popularly used. Paul glister, a historian and educator first coined the term "digital literacy," in the year 1997 arguing that digital literacy went beyond just skills in using technology. He said it is about "mastering ideas, not [computer] keystrokes" (glister, 1997, p. 1). glister (1997) further defined digital literacy as "the ability to understand and use information in multiple formats from a wide range of sources when it is presented via computers" ( $p$. 1). NEP 2020 has also emphasized on digital India campaign and the use of emerging technologies in the field of education. It also suggested for using ICT applications and training if teachers towards digital literacy and online teaching and learning process due to frequent occurrence of pandemic situation.

\section{Review of Related Literature}

Recently many researchers have conducted various studies in the field of digital literacy in different levels of education. Digital literacy is not a reality that has favored the teaching-learning process and a training program is urgently required for teachers to reach optimal levels of digital skills, so as to undergo a true paradigm shift, ultimately coordinating methodology and educational strategies (Cristina et al. 2021). Some teachers also having difficulty using applications related to photo processing (Santi et al. 2020). Educational institutions should conduct plenty of research when bringing the right technology for different educational initiatives (Dhawan 2020). Higher secondary school teachers from English medium, teachers from urban areas and matriculation higher secondary school teachers are better in their ICT awareness than their counter parts (Sivasankar and Dutta 2019) found that young users of digital media are more efficient and comfortable than the adult users as adult users show fear and uncomfortable to use digital technologies Jayavel, 2019) in his study teaching competency of English teachers in relation to digital literacy, work values and personality traits found that English 
language teachers are having high level of teaching competence, digital literacy is average, positive work values and desirable personality. There is positive and significant relationship between teaching competence and digital literacy, work values and personality traits of English language teachers. Srivastava (2019) in his study on digital competence and life skills: a study of higher education teachers found that the teachers need to develop critical evaluation skills, constructive online interactive and collaborative competencies, and creative potential, which are necessary for the successful $21^{\text {st }}$ century digital citizenship; we may hope for a better generation with humanizing technology. Velmani (2018) in her study on technology literacy among the school teachers found that the teachers' age, gender, general educational qualification, working experience, type of school, computer operating knowledge, possessing e-mail address, having own personal computer and regular internet browsing habit are affecting their attitude towards mobile learning.

\section{Rationale of the Study}

Digital technologies have touched almost all the aspects of human life including education. It should be used in school education for quality improvement of education in schools. Therefore the teachers in the present day's era should not only have mastery over the content knowledge, but also, they should have variety of pedagogical skills well as technological knowledge so that they can teach the students in an advanced way. As pandemic situation is going on, so it's very essential for the teachers to use digital technology for lesson preparation, lesson delivery and following up of the lesson in school. They can also use technology for assessment and evaluating learners progress by using digital portfolio, online assessment etc. For this purpose, the government of India and states has provided ICT facilities to all schools but due to lack of interest and digital knowledge of teachers it is not working fruitfully. After analyzing the reviews in the above paragraph the researcher found that no studies has been conducted in the use of digital technology and status of digital literacy in secondary school in Odisha. Hence the researcher shows interest to undertake a research work in that particular area.

\section{Statement of the Problem}

Digital literacy is the ability to prepare, transact, and evaluate different works with the help of digital technologies which is the need of the hour. Hence the study is entitled as "Status and issues of digital literacy of secondary school teachers".

\section{Operational Definition of Key Terms}

Status : It refers to the degree of using digital technologies.

Issues: It refers to the problems faced by the secondary school teachers to use digital technologies.

Digital literacy: It refers to the ability of secondary school teachers to use digital technologies, applications, devices in the teaching learning process.

Secondary school teachers: Here secondary school teachers refer to those teachers who are working in lower secondary schools in Odisha.

\section{Objectives of the Study}

The present study has the following objectives:

1. To study the status of digital literacy of secondary school teachers.

2. To find out the challenges faced by the teachers while using digital technologies.

3. To study the purpose of using digital devices by the secondary school teachers in the teaching learning process.

\section{Research Questions}

The following research questions have been formulated to examine the status and issues of digital literacy of secondary school teachers.

1. What is the present status of digital literacy of secondary school teachers?

2. What are the challenges faced by the teachers while using digital technologies?

3. For which purpose the second school teachers are using digital technologies?

4. What strategies should be implemented to shutout the issues?

\section{Delimitation of the Study}

The study is limited to only 40 secondary school teachers of Odisha. It has aimed only to study the 
status and issues of digital literacy of secondary school teachers in the state of Odisha.

\section{Methodology}

For the conducting the present study descriptive survey method was used to examine the status and issues of the digital literacy of secondary school teachers. For selecting the sample for the present study purposive sampling technique was used. The sample was selected purposively from different high schools from different districts in Odisha state. 40 numbers of secondary school teachers (18 male and 22 female) were selected.

\section{Tools Used}

A self-developed questionnaire consisting of 34 objective type and 2 open ended questions based on different aspects of digital literacy, it's use, competency of teachers of using digital technologies, general awareness, problem in schools, and strategies to improve the condition had formulated by the researcher. The validity of the tool was ensured by taking the comments of experts.

\section{Procedure of Data Collection}

The data have been collected in online mode only through Google form and telephonic interview.
While collecting data, a friendly environment was created to collect reliable data from the primary sources.

\section{Data Analysis Procedure}

After collecting relevant data from the respondents, the data was analyzed quantitatively by using simple frequency and percentage. The remarks and suggestions of the respondents were analyzed qualitatively and interpretation was made accordingly.

\section{Data Analysis and Interpretation}

As per the objectives of the study the collected data are analyzed by using frequency and percentage and qualitative descriptions. The detailed analysis and interpretation are given below.

Table 1 indicates that the typing skill, computer literacy, internet literacy, digital literacy and web search skills of secondary school teachers are good i.e. around $50 \%$. Very few teachers have very poor digital literacy skills.

Table 2 indicates the digital device using skills. $65 \%$ teachers said that they can change of screen brightness and contrast where as $87.5 \%$ said that they can minimize, maximize and move the windows. Scan disks/pen drive for viruses and

Table 1: Rate of digital literacy skills

\begin{tabular}{llllll}
\hline $\begin{array}{l}\text { Rate of Digital } \\
\text { Literacy Skills }\end{array}$ & $\begin{array}{l}\text { Very Poor } \\
\text { (Frequency \& \%) }\end{array}$ & $\begin{array}{l}\text { Poor (Frequency } \\
\& \%)\end{array}$ & $\begin{array}{l}\text { Acceptable } \\
\text { (Frequency \& \%) }\end{array}$ & $\begin{array}{l}\text { Good (Frequency } \\
\text { \& \%) }\end{array}$ & $\begin{array}{l}\text { Very Good } \\
\text { (Frequency \& \%) }\end{array}$ \\
\hline Typing Skills & $2(5 \%)$ & $4(10 \%)$ & $10(25 \%)$ & $19(47.5 \%)$ & $5(12.5 \%)$ \\
Computer Literacy & $2(5 \%)$ & $3(7.5 \%)$ & $12(30 \%)$ & $20(50 \%)$ & $3(7.5 \%)$ \\
Internet Literacy & $1(2.5 \%)$ & $4(10 \%)$ & $10(25 \%)$ & $21(52.5 \%)$ & $4(10 \%)$ \\
Digital Literacy & $2(5 \%)$ & $5(12.5 \%)$ & $9(22.5 \%)$ & $20(50 \%)$ & $4(10 \%)$ \\
Web Search Skills & $1(2.5 \%)$ & $4(10 \%)$ & $12(30 \%)$ & $19(47.5 \%)$ & $4(10 \%)$ \\
\hline
\end{tabular}

Table 2: Digital Device Using Skills

\begin{tabular}{ll}
\hline Digital device using skills & Yes (Frequency \& \%) \\
\hline Change of screen brightness and contrast & $26(65 \%)$ \\
Minimize, maximize and move the windows & $35(87.5 \%)$ \\
Use a 'search' command to locate a file & $28(70 \%)$ \\
Scan disks/pen drive for viruses & $13(32.5 \%)$ \\
Write files onto USB drive & $13(32.5 \%)$ \\
Create and update web pages & $08(20 \%)$ \\
Record and edit digital and video sounds & $12(30 \%)$ \\
Download and install applications & $33(82.5 \%)$ \\
Share photos and videos in social media & $38(95 \%)$ \\
\hline
\end{tabular}


write files onto USB drive activity is not satisfactory in them as only $32.5 \%$ teachers said that they can do these. Creating and uploading web pages can't be done by most of the teachers. But downloading and installing applications as well as social media use can be done by most of them i.e. $82.5 \%$ and 95\% respectively.

Table 3: Awareness about digital devices

\begin{tabular}{ll}
\hline Items & $\begin{array}{l}\text { Yes (Frequency } \\
\& \%)\end{array}$ \\
\hline $\begin{array}{l}\text { Do you understand the basic functions } \\
\text { of computer hardware components? }\end{array}$ & $33(82.5 \%)$ \\
$\begin{array}{l}\text { Do you have a personal homepage or a } \\
\text { personal portfolio on the web? }\end{array}$ & $1(2.5 \%)$ \\
$\begin{array}{l}\text { Do you use keyboard shortcuts? } \\
\text { Do you use the computer for learning } \\
\text { purposes? }\end{array}$ & $23(57.5 \%)$ \\
$\begin{array}{l}\text { Do you find it easy to learn something } \\
\text { by reading it on the computer screen? }\end{array}$ & $27(67.5 \%)$ \\
$\begin{array}{l}\text { Do you find it easy to learn something } \\
\text { by watching it on the computer screen? }\end{array}$ & $27(67.5 \%)$ \\
$\begin{array}{l}\text { Do you use social networking services? } \\
\text { Do you have any online friend you }\end{array}$ & $31(77.5 \%)$ \\
$\begin{array}{l}\text { have never met in person? } \\
\begin{array}{l}\text { Do you feel competent in using digital } \\
\text { learning resources? }\end{array}\end{array}$ & $20(50 \%)$ \\
$\begin{array}{l}\text { Do you have mobile apps you use for } \\
\text { language learning purposes? }\end{array}$ & $25(62.5 \%)$ \\
\hline
\end{tabular}

Table 3 indicates general awareness of secondary school teachers on digital devices. Most of the teachers $(82.5 \%$ ) said that they understand the basic functions of computer hardware components but only $2.5 \%$ teacher has personal home page and portfolio. Some teachers $(57.5 \%)$ said they can do computer shortcut key functions. Most of them are using computer for teaching learning process. $67.5 \%$ if teachers agreed that working something on computer screen is comfortable. Most of them are active in social networking sites and making friends on that platform. Half of them are agreed that they are competent in using digital learning resources.

Table 4 indicates the purpose of using digital technologies in teaching-learning process by the teachers. Most of them are using digital technologies for sharing notes with students in online mode (67.5\%) and collecting resource for teaching (63.5\%). Only 25\% teachers agreed that they are preparing online exercises, tasks and digital materials for the students. Few of them (20\%) know how to provide feedback in online mode.

Table 4: Purpose of using digital technology in teaching learning process

\begin{tabular}{ll}
\hline Items & $\begin{array}{l}\text { Yes (Frequency } \\
\text { \& \%) }\end{array}$ \\
\hline Prepare Lesson Plan & $7(18.4 \%)$ \\
Collect Resources for Teaching & $24(63.2 \%)$ \\
Use Ppt for Teaching & $9(22.5 \%)$ \\
Create Digital Learning Materials for & $10(25 \%)$ \\
Students & \\
Prepare Online Exercise and Tasks & $10(25 \%)$ \\
for Students & \\
Provide Feedback to Students Online & $08(20 \%)$ \\
Uses Online Library & $12(30 \%)$ \\
Use Video Clips for Teaching & $10(25 \%)$ \\
Share Notes With Students Online & $27(67.5 \%)$ \\
\hline
\end{tabular}

Table 5 reflect upon the factors that affect the digital literacy of the teachers. Most of them (85\%) state that training is not sufficient.

Table 5: Factors affecting digital literacy

\begin{tabular}{ll}
\hline Items & $\begin{array}{l}\text { Agree } \\
\text { (Frequency \& \%) }\end{array}$ \\
\hline Lack of time & $20(50 \%)$ \\
Lack of budget & $16(40 \%)$ \\
Lack of knowledge of teachers & $21(52.5 \%)$ \\
Lack of knowledge of students & $06(15 \%)$ \\
Lack of skills of teachers & $21(52.5 \%)$ \\
Lack of skills of students & $06(15 \%)$ \\
Lack of interest of teachers & $10(25 \%)$ \\
Lack of interest of students & $03(7.5 \%)$ \\
Lack of training & $34(85 \%)$ \\
Lack of learning materials & $15(37.5 \%)$ \\
Lack of supporting resources & $14(35 \%)$ \\
Lack of facilities & $18(45 \%)$ \\
\hline
\end{tabular}

Though there is satisfactory supporting resources around half of the teachers agreed that due to lack time, knowledge on digital literacy, essential skills and facilities the process of digital literacy is hampering.

Most of the teachers are using google meet and zoom apps to teach the students in online mode. 
They state that due to insufficient training digital literacy level is low in Odisha so each and every school should have adequate computer facilities and computer teachers. In-service training program should be done frequently in order to shutout the problems.

\section{Major Findings of the Study}

1. Typing skill, computer literacy, internet literacy, digital literacy and web search skills of secondary school teachers are good i.e. around $50 \%$. Very few teachers have very poor digital literacy skills.

2. $65 \%$ teachers said that they can change of screen brightness and contrast where as $87.5 \%$ said that they can minimize, maximize and move the windows. Scan disks/pen drive for viruses and write files onto USB drive activity is not satisfactory in them as only $32.5 \%$ teachers said that they can do these. Creating and uploading web pages can't be done by most of the teachers. But downloading and installing applications as well as social media use can be done by most of them i.e. $82.5 \%$ and $95 \%$ respectively.

3. Most of the teachers (82.5. \%)said that they understand the basic functions of computer hardware components but only $2.5 \%$ teacher has personal home page and portfolio. Some teachers $(57.5 \%)$ said they can do computer shortcut key functions. Most of them are using computer for teaching learning process. $67.5 \%$ if teachers agreed that working something on computer screen is comfortable. Most of them are active in social networking sites and making friends on that platform. Half of them is agreed that they are competent in using digital learning resources.

4. Most of the teachers are using digital technologies for sharing notes with students in online mode $(67.5 \%)$ and collecting resource for teaching (63.5\%). Only 25\% teachers agreed that they are preparing online exercises, tasks and digital materials for the students. Few of them $(20 \%)$ know how to provide feedback in online mode.
5. Most of them $(85 \%)$ state that training is not sufficient. Though there is satisfactory supporting resources around half of the teachers agreed that due to lack time, knowledge on digital literacy, essential skills and facilities the process of digital literacy is hampering.

6. Most of the teachers are using google meet and zoom apps to teach the students in online mode.

7. They state that due to insufficient training digital literacy level is low in Odisha so each and every school should have adequate computer facilities and computer teachers. In-service training program should be done frequently in order to shutout the problems.

8. Teachers below age group of 35-40 are more efficient in using digital technologies than the adults.

9. The study also found out that TGT science teachers are more efficient than the TGT arts teachers.

\section{Educational implications}

1. The study will be helpful for the teachers to adopt innovative approaches to improve the classroom transaction.

2. The study will be helpful for the all-round development of the school process.

3. The study will be helpful for organizing the in-service training programme for digital literacy.

4. The study will be helpful for administrational bodies in organizing in-service training for teachers to equip them with new knowledge and skills for making classroom effective.

5. This will be very helpful for the distance learners.

6. It will be very helpful for online learning programs specially to meet the educational challenges in the pandemic situations.

7. It will also be helpful for the administrative bodies as well as the government for creating innovative strategies to improve the secondary school conditions in Odisha with reference to digital literacy. 


\section{Suggestions for Further Research}

The present study is confined to check the statue and issues of digital literacy of secondary school teachers in Odisha. It can be suggested that comparative studies between govt and private schools can be undertaken. Status of digital literacy of primary school teachers, higher secondary and higher education teachers can be studied further. Comparative studies can be undertaken between various levels of education.

\section{CONCLUSION}

It can be briefly concluded that digital devices and applications are widely using by the schools. Various committees and commissions have also emphasized to use digital technologies in educational field. Nep 2020, NCTE regulation 2014 has also emphasized on digital literacy and applications of ICT in the teaching learning process. Government of India has launched the various programmes like digital India campaign, e-pathshala, NROER, SWAYAM, SWAYAMPRAVA, NDL India etc. for facilitating the use of ICT in educational context. In the present study it is clear that most of the teachers are competent in using smart phones but due to lack of training and guidance programs they are unable to use the resources properly. So,Govt. Should take initiative for shutting out the problem by undertaking frequent in-service training program as well as providing sufficient infrastructure to the schools.

\section{REFERENCES}

Chaudhary, P. 2014 Effectiveness of intel teach program on attitude towards ICT, digital literacy and study process of teacher educators. http://hdl.handle.net/10603/54592

Cristina Sanchez-Cruzado, Raul Santiago Campion and M. Teresa S nchez-Compana. 2021. Teacher Digital Literacy: The Indisputable Challenge After Covid-19. https://www. mdpi.com/2071-1050/13/4/1858

Deepamala, M.A. 2018. Impact of Information Literacy Skills Among Women Faculty Members in Engineering Colleges in Coimbatore Region. http://hdl.handle. net/10603/279746d.

Dhawan, S. 2020 Online Learning: A Panacea in the Time of COVID-19 Crisis. https://journals.sagepub.com/doi/ full/10.1177/0047239520934018

Dutta, S. 2019. Digital Media Literacy Among Adult Users in Assam. http://hdl.handle.net/10603/284998
Emream, M bin Kiyici. 2017. Perceptions of Prospective Teachers on Digital Literacy. https:/files.eric.ed.gov/ fulltext/ej1156711.pdf

Jayavel, G. 2019. Teaching Competency of English Teachers in Relation to Digital Literacy, Work Values and Personality Traits. http://hdl.handle.net/10603/321315

Hemavathi, K.N. 2019 Information Literacy Competency Among Students and Faculty Members of Horticultural Science Institutions in Karnataka. http://hdl.handle. net $/ 10603 / 323260$

Kamatchi, S. 2013. Development of A Web Enabled Information Literacy Module and its Effectiveness Among the Students in Chennai. http://hdl.handle.net/10603/22213

Lata, S. 2014. Information Literacy Among Faculty and Students of Medical Colleges of Haryana, Punjab and Chandigarh. http://hdl.handle.net/10603/38821

Mahesh M. Dalvi. 2018. Information Literacy of Undergraduate Students: Assessment of Competencies and Proficiencies. http://hdl.handle.net/10603/259848

MHRD. 2012. national policy on ICT in school education. Department of Education and Literacy, MHRD, Government of India.

Mohalik, R. 2020. Digital Literacy and its Use by Teacher Trainees at Secondary Level in Odisha. https:// juniperpublishers.com/ttsr/ttsr.ms.id.555631.php

Nisha, N.B. 2016. Information Literacy Competency of Agricultural Scientists in Kerala. http://hdl.handle. net/10603/209183

Velmani, P. 2018. A Study of Technology Literacy Among the School Teachers in Sriperumpudur Taluk. http://hdl. handle.net/10603/232472

Pandurang Mahadik A. 2019. Digital Literacy Among Users in Law Institute Libraries in Pune: A Study. http://hdl. handle.net/10603/286557

Vijaya Kumari, S.N. and Flavia D'Souza. 2016. Secondary School Teachers' Digital Literacy and Use of ICT in Teaching and Learning. https://zenodo.org/record/220927\#.yrjzos0zz0w

Santi Susanti, Rachmaniar, Fitri Perdana. 2020. Digital Literacy of Teachers in Online Learning at Elementary School in Bandung City. https://ejmcm.com/article_4190.html

Santiago Tejedor, Laura Cervi, Ana Perez-escoda and Fernanda Tusa Jumbo. 2020. Digital Literacy and Higher Education During Covid-19 Lockdown: Spain, Italy, and Ecuador. https://www.mdpi.com/2304-6775/8/4/48

Shwetha Kumari, K. 2018. A Study of Information Literacy and Information Fluency of Faculty Members and Research Scholars at Government Arts and Science Colleges in Tamil Nadu. http://hdl.handle.net/10603/135947

Singh, M. 2019. Teaching Competence of Prospective Teachers in Relation to Their Digital Literacy, Inspirational Leadership and Creative Intelligence. http://hdl.handle. net/10603/304098 
Srivastava, S. 2019. Digital Competence and Life Skills: A Study of Higher Education Teachers. http://hdl.handle. net/10603/285777

Titis Angga Rini, Bagus Cahyanto, Febrianita Putri Sholihah. 2020. The Portraits of Digital Literacy Awareness Amid Covid-19 Pandemic. https://www.atlantis-press.com/ proceedings/icet -20/125947598

Umamaheswar. 2019. A Study on Information Literacy Skills Among the Faculty Members of Nursing Colleges in Tamil Nadu. http://hdl.handle.net/10603/315759

Vellaichamy, A. 2017. Information Literacy Skills in the Use of Electronic Resources Among the Faculty Member Teresa Women's University and its Affiliated Colleges. http://hdl. handle.net/10603/229132
https://juniperpublishers.com/ttsr/TTSR.MS.ID.555631.php https://dougbelshaw.com/blog/2007/07/25/definitions-ofdigital-literacy-from-the-book-of-the-same-name-bypaul-gilster/

https://qy.querackwom.space/59.html

https://files.eric.ed.gov/fulltext/EJ1156711.pdf

https://1library.net/document/yn425ppz-perceptions-ofprospective-teachers-on-digital-literacy.html

https://journals.sagepub.com/doi/full/10.1177/ 0047239520934018 